\title{
ARTIKELEN
}

\section{Burgerparticipatie onder de Omgevingswet: niet omdat het moet, maar omdat het kan?!}

\author{
De juridische waarborging van burgerparticipatie in de \\ Omgevingswet
}

\author{
Marlon Boeve \& Frank Groothuijse
}

\section{Inleiding}

Burgerjury's, klankbordpanels, ontwerpateliers... het bevorderen van participatie van burgers bij projecten in de fysieke leefomgeving zoals windmolenparken, uitbreiding van wegen en buurttuinen is een hot topic. Ook bij de totstandkoming van de Omgevingswet is participatie een belangrijk onderwerp. Op talrijke plaatsen in de parlementaire stukken bij de Omgevingswet wordt het belang van participatie door de regering benadrukt.

In de Omgevingswet wordt onder participatie verstaan: het in een vroegtijdig stadium betrekken van belanghebbenden (burgers, bedrijven, maatschappelijke organisaties en andere overheden) bij het proces van de besluitvorming over een project of activiteit. ${ }^{1}$ Daaronder vallen niet alleen de formele momenten waarop partijen op grond van de wet zienswijzen kunnen indienen, maar juist ook het betrekken van partijen bij het besluitvormingsproces voordat de formele besluitvormingsprocedure aanvangt. Het doel is drieledig: met het bevorderen van een vroegtijdige betrokkenheid van burgers bij ontwikkelingen voor de fysieke leefomgeving wordt beoogd: 1) de kwaliteit en 2) de snelheid van de besluitvorming te vergroten en 3) meer draagvlak te creëren voor de uiteindelijk te nemen besluiten. Een versnelling van de besluitvorming zou onder meer worden bewerkstelligd door een afname van het aantal zienswijzen en bezwaar- en beroepsprocedures, omdat al aan de 'voorkant' van de besluitvorming wordt meegedacht over nieuwe ontwikkelingen. ${ }^{2}$ De ruimte voor het bevorderen van die betrokkenheid wordt, aldus de regering, 'meer dan nu het geval is, in de Omgevingswet geboden'. ${ }^{3}$

In deze bijdrage zullen wij bezien op welke wijze in de Omgevingswet juridisch invulling wordt gegeven aan de doelstellingen die de regering op het gebied van

1 Zie Stb. 2018/290, p. 133 en Kamerstukken II 2013/14, 33962, 3, p. 389.

2 Zie over de doelstelling van participatie o.a. Kamerstukken II 2013/14, 33962, 3, p. 217; Kamerstukken II 2014/15, 33962, 12, p. 131 en 'Nota van Toelichting bij het Omgevingsbesluit', Stb. 2018, 290, p. 132.

3 Nota naar aanleiding van verslag, Kamerstukken II 2014/15, 33962, nr. 12, p. 131. 
participatie met deze wet nastreeft en of de betrokkenheid van burgers daadwerkelijk juridisch beter is geborgd.

Wij zullen daarbij ingaan op het belangrijke punt van het 'juiste moment' van participeren. Het 'missen' van een participatietraject kan immers grote gevolgen hebben. Indien bijvoorbeeld bij de realisering van een windmolenpark het participatiemoment bij de omgevingsvisie wordt gemist en pas in het vergunningentraject wordt ingesproken, zal de locatiekeuze niet meer ter discussie staan, maar kan het in beginsel alleen nog gaan over de uitvoeringsaspecten. ${ }^{4}$ Ons inziens komen de participatieverplichtingen in de Omgevingswet niet tegemoet aan deze problematiek. Een ander belangrijk punt is de vraag welke juridische gevolgen de rechter verbindt (of kan verbinden) aan het niet naleven van de wettelijke participatieverplichtingen door bestuursorganen bij het vaststellen van plannen en besluiten. Kan een burger participatie afdwingen bij de bestuursrechter na inwerkingtreding van de Omgevingswet? De mogelijkheden daartoe zijn zeer beperkt.

Onze stelling is dan ook dat de Omgevingswet niet tegemoetkomt aan de wezenlijke problemen die zich voordoen bij participatie. Het succesvol creëren van lokaal draagvlak, een betere kwaliteit en snellere besluitvorming door participatie zijn afhankelijk van hoe het bestuur de participatie vormgeeft. Juridisch levert de Omgevingswet hier weinig bijdrage aan.

De opzet van deze bijdrage is als volgt. In paragraaf 2 wordt eerst kort ingegaan op de spanning die kan bestaan tussen het bevorderen van participatie en de democratische legitimiteit van besluitvorming. In paragraaf 3 wordt een beschrijving gegeven van de wijze waarop burgerparticipatie is geregeld onder de Omgevingswet, waarbij ook wordt bezien in hoeverre de juridische regeling meer ruimte laat voor participatie dan het huidige recht. Vervolgens wordt in paragraaf 4 ingegaan op de problematiek van het juiste moment van participatie. In paragraaf 5 worden de mogelijkheden tot het afdwingen van naleving van participatieverplichtingen bij de rechter nader belicht. Deze bijdrage wordt in paragraaf 6 afgesloten met een conclusie en enkele oplossingsrichtingen.

\section{Spanning tussen participatie en democratische legitimatie van besluitvorming}

Een belangrijk doel van participatie is het creëren van meer draagvlak voor de uiteindelijke besluitvorming. Uit de Awb vloeit reeds voort dat een bestuursorgaan een besluit zorgvuldig moet voorbereiden, de nodige kennis moet vergaren over de relevante feiten en de af te wegen belangen, de belangen van derden bij de besluitvorming moet betrekken en het te nemen besluit niet onevenredig mag zijn voor een of meer belanghebbenden in verhouding tot de met het besluit te dienen doelen. ${ }^{5}$ Ook schrijft de Awb expliciet voor dat een besluit moet worden gemotiveerd. ${ }^{6}$

4 Zie bijvoorbeeld De Haas \& Tsheichvili 2018 en Akerboom 2018.

5 Zie art. 3:2 en 3:4 Awb.

6 Art. 3:46 Awb. Zie hierover in algemene zin bijvoorbeeld Broring \& De Graaf 2016, hoofdstuk 7 en 8 . 
Los van concrete wettelijke participatieverplichtingen in sectorale wetgeving zoals de Omgevingswet, zullen deze bepalingen uit de Awb ook nopen tot het raadplegen van het publiek bij de voorbereiding van besluiten en het motiveren hoe deze inbreng is meegewogen in de besluitvorming.

De vroegtijdige inbreng van burgers speelt dus reeds op basis van de Awb een rol bij het maken van de belangenafweging door het bestuursorgaan. Een doorslaggevende rol in deze belangenafweging heeft participatie en in het bijzonder het creëren van draagvlak evenwel niet. Zo zal het bestuursorgaan de inbreng van burgers, zoals argumenten tegen de specifieke locatie van een windmolenpark, moeten meewegen in de besluitvorming, maar kan er ook een besluit worden genomen dat niet tegemoetkomt aan deze belangen. De participatieverplichtingen in de Omgevingswet brengen hier geen verandering in. Ons inziens is dit ook terecht. Een wettelijke verplichting waarbij het creëren van draagvlak een voorwaarde is voor besluitvorming, zou op zeer gespannen voet staan met (het ontbreken van) democratische legitimiteit. Het (overheids)bestuur moet immers besluiten nemen waarbij rekening wordt gehouden met de belangen van alle burgers, niet alleen met de belangen van diegenen die hebben ingesproken. ${ }^{7}$ Daarnaast moeten zij rekening houden met publieke belangen, zoals natuur, cultuurhistorie en beschikbare budgetten, etc.

\section{Hoe is burgerparticipatie geregeld onder de Omgevingswet?}

\subsection{Algemeen}

Uit de door de regering gegeven omschrijving van 'participatie' (zie par. 1) blijkt dat het gaat om betrokkenheid voorafgaand aan het te nemen besluit. Wat moet hier precies onder worden verstaan? Participatie voorafgaand aan het besluit kan immers zowel zien op informele participatie bij de voorbereiding van het besluit, als op de formele zienswijzenprocedure op grond van afdeling 3.4 Algemene wet bestuursrecht, waarbij zienswijzen kunnen worden ingebracht tegen het ontwerpbesluit. Beide vormen van inspraak vinden plaats voorafgaand aan het te nemen besluit. $^{8}$ Inhoudelijk maakt het niet uit welke vorm van participatie wordt gevolgd, in zowel het informele traject als bij het indienen van zienswijzen kunnen enerzijds 'bottom-up' initiatieven naar voren worden gebracht en kan anderzijds worden gereageerd op initiatieven van het bestuursorgaan of anderen. Juridisch hebben beide vormen van participatie echter wel een verschillende consequentie. Het missen van het formele traject (het indienen van zienswijzen) kan gevolgen hebben voor de rechtsbescherming in de zin dat een belanghebbende niet in beroep kan gaan tegen het besluit als niet de zienswijzeprocedure is gevolgd (zie verder par. 5). Informele participatie dient niet als een dergelijke juridische toegangspoort voor de bestuursrechter. Voor een burger kan het dan ook verwarrend zijn als blijkt dat het participeren in het informele traject niet voldoende is geweest om toegang te krijgen tot de bestuursrechter.

7 Dit blijkt ook uit jurisprudentie: ABRvS 21 februari 2018, ECLI:NL:RVS:2018:616 (Drentse Monden) en ABRvS 3 april 2019, ECLI:NL:RVS:2019:1064. Zie ook Uylenburg 2019.

8 Dit is anders bij de bezwaarschriftenprocedure, dan is het besluit al genomen. 
Hoe ruim 'participatie' precies moet worden opgevat onder de Omgevingswet blijkt echter niet eenduidig uit de toelichting op de Omgevingswet en de uitvoeringsregelgeving. Zo lijkt in de Memorie van Toelichting (MvT) de zienswijzenprocedure niet onder de noemer van 'participatie' te worden geschaard: 'Naast participatie zijn zienswijzenprocedures voor bestuursorganen een belangrijk hulpmiddel bij de belangenafweging die noodzakelijk is voor besluitvorming. ${ }^{9}$ In de Nota van Toelichting (NvT) bij het Omgevingsbesluit wordt echter opgemerkt: 'Participatie is meer dan de formele momenten waarop alle partijen zienswijzen kunnen indienen. Het betreft juist het betrekken van partijen bij het besluitvormingsproces voordat de formele besluitvorming van start gaat. De zienswijzenprocedure is wel een vorm van participatie. ${ }^{\prime 10}$ Wij sluiten in deze bijdrage aan bij deze ruimere invulling, waarbij ook de zienswijzenprocedure onder het participatiebegrip valt.

De inrichting van formele participatie - het indienen van zienswijzen - is wettelijk geregeld, zoals de voorgeschreven wettelijke termijnen. Voor de inrichting van de informele participatie in de voorfase zijn bewust geen wettelijke regels opgenomen om bestuursorganen de vrijheid te geven het participatieproces zelf in te richten en maatwerk te leveren. Deze informele vorm van participatie is dan ook vormvrij en kan verschillende vormen aannemen, zoals raadspanels, ontwerpateliers, klankbordgroepen, enquêtes, internetconsultaties, etc. ${ }^{11}$ De regering wijst er meermalen op dat het juridisch voorschrijven van de wijze waarop vroegtijdige participatie moet plaatsvinden zou leiden tot juridisering van de voorbereiding van besluiten, terwijl het juist gaat om een professionele bestuurlijke aanpak die zich niet juridisch laat afdwingen. ${ }^{12}$ De regering wil dan ook niet meegaan in de wens van verschillende politieke partijen om de toepassing van de 'Code Maatschappelijke Participatie'13 verplicht voor te schrijven bij de voorfase van de besluitvorming. ${ }^{14}$ In het oorspronkelijke wetsvoorstel Omgevingswet was alleen voor het projectbesluit een aanvullende wettelijke regeling voor participatie opgenomen. Uiteindelijk zijn er als gevolg van toezeggingen aan de Tweede Kamer en amendementen toch bij meer juridische instrumenten, zoals het omgevingsplan en de omgevingsvergunning participatieverplichtingen opgenomen. ${ }^{15}$ Deze bepalingen zijn zowel te vinden in de Omgevingswet, het Omgevingsbesluit als in de Omgevingsregeling. ${ }^{16}$ De Invoeringswet Omgevingswet heeft daarbij

$9 \quad$ Kamerstukken II 2013/14, 33962, 3, p. 218.

10 NvT bij het Omgevingsbesluit, Stb. 2018, 290, p. 131.

11 Zie NvT bij het Omgevingsbesluit, Stb. 2018, 290, p. 132.

12 Zie o.a. Kamerstukken II 2014/15, 33962, 12, p. 132, Kamerstukken II 2013/14, 33962, 3, p. 217 en NvT bij het Omgevingsbesluit, Stb. 2018, 290, p. 133.

13 De Code Maatschappelijke participatie is opgesteld door het ministerie van Infrastructuur en Waterstaat, te raadplegen via www.platformparticipatie.nl.

14 Zie o.a. Kamerstukken II 2014/15, 33962, 12, p. 132 en Kamerstukken II 2014/15, 33962, 23, p. 126.

15 Zie o.a. Kamerstukken II 2014/15, 33962, 23, par. 1.2.3.

16 De laatste versies zijn makkelijk vindbaar via www.omgevingswetportaal.nl. Van de Omgevingsregeling is op moment van schrijven de internetconsultatieversie beschikbaar. 
nieuwe bepalingen over participatie aan de Omgevingswet toegevoegd. ${ }^{17}$ Deze wet ligt op het moment van schrijven bij de Eerste Kamer. Hieronder bespreken we de voor participatie relevante regelingen per instrument. Daarbij zal telkens een korte vergelijking worden gemaakt met het huidige recht. Deze vergelijking laat zien dat de juridische regeling onder de Omgevingswet maar weinig meer 'harde' participatieverplichtingen kent dan het huidige recht.

\subsection{Omgevingsvisie en programma's}

In hoofdstuk 3 van de Omgevingswet zijn de instrumenten voor beleidsplanning geregeld. In de omgevingsvisie en het omgevingsprogramma leggen bestuursorganen hun strategische omgevingsbeleid vast. Voor zowel de omgevingsvisie als het omgevingsprogramma is in de Omgevingswet een motiveringsplicht opgenomen ten aanzien van vroegtijdige publieksparticipatie. Bij het vaststellen van een omgevingsvisie respectievelijk een omgevingsprogramma 'wordt aangeven hoe burgers, bedrijven, maatschappelijke organisaties en bestuursorganen bij de voorbereiding zijn betrokken en wat de resultaten daarvan zijn'. ${ }^{18}$ Er wordt conform het uitgangspunt van de regering niet bepaald op welke wijze de participatie moet worden vormgegeven. Naast deze vroegtijdige participatie (voordat er een ontwerp is) kunnen betrokkenen ook formeel hun zienswijzen inbrengen op het moment dat de ontwerp-visie of het ontwerp-programma ter inzage is gelegd. ${ }^{19}$ Er staat echter geen bestuursrechtelijke rechtsbescherming open tegen de omgevingsvisie en het omgevingsprogramma. ${ }^{20}$ Dit betekent dat wanneer geen gelegenheid is geboden tot vroegtijdige participatie of het inbrengen van zienswijzen, dit niet aan de bestuursrechter kan worden voorgelegd.

Wanneer een vergelijking wordt gemaakt met het huidige recht, zien we slechts een beperkte versterking van de participatieregeling bij beleidsplannen. Ook in het huidige recht geldt de plicht dat bij een structuurvisie wordt aangegeven op welke wijze burgers en maatschappelijke organisaties bij de voorbereiding daarvan zijn betrokken. ${ }^{21}$ Onder de Omgevingswet is deze verantwoordingsverplichting enigszins versterkt in de zin dat expliciet is bepaald dat ook de resultaten moeten worden verantwoord. Zoals gezegd, kan deze verantwoording (of de afwezigheid daarvan) echter niet ter toetsing aan de bestuursrechter worden voorgelegd. Ten opzichte van het huidige recht kent de Omgevingswet ook een beperkte 'verzwakking' van de participatieregeling bij beleidsplannen. Thans is voorgeschreven dat bij de kennisgeving van het voornemen tot voorbereiding van een structuurvisie wordt aangegeven of en op welke wijze zienswijzen naar voren kun-

17 Wij gaan in het navolgende uit van de tekst van de geconsolideerde versie van de Omgevingswet zoals te vinden op www.omgevingswetportaal.nl.

18 Art. 10.7 en 10.8 Omgevingsbesluit.

19 Afd. 3.4 Awb is van toepassing op de voorbereiding (zie art. 16.26 en 16.27 Omgevingswet).

20 Bijlage 2 Awb, zoals gewijzigd bij Invoeringswet Omgevingswet, Kamerstukken II 2018/19, 34986, A. Voor zogenoemde programma's met een programmatische aanpak geldt overigens een uitzondering, voor zover het activiteiten betreft die als gevolg van opname in het programma vergunningvrij zijn (bijlage 2 Awb, art. 1 Omgevingswet onderdeel f). Tegen deze onderdelen staat wel rechtsbescherming open.

21 Art. 2.1.1 Besluit ruimtelijke ordening. 
nen worden gebracht over dit voornemen. ${ }^{22}$ Op deze wijze worden burgers vroegtijdig geïnformeerd over de participatiemogelijkheden. Deze bepaling komt onder de Omgevingswet voor omgevingsvisies niet terug. ${ }^{23}$

\subsection{Algemene regels: rijksregels en omgevingsplan}

- $\quad$ Rijksregels

Net als het huidige omgevingsrecht, kenmerkt ook de toekomstige omgevingswetgeving zich door gedelegeerde regelgeving. De Omgevingswet kan vooral worden gezien als een kaderwet, waarvan de inhoud verder wordt uitgewerkt bij $\mathrm{AMvB}$ en ministeriële regeling. Ten aanzien van deze uitvoeringsregelingen bevat de Omgevingswet een regeling over publieksparticipatie. Via internetconsultatie moet een ieder in de gelegenheid worden gesteld om gedurende ten minste vier weken opmerkingen te maken over het ontwerp van de $\mathrm{AMvB}$ of ministeriële regeling. ${ }^{24}$ Dit betreft dus ook toekomstige wijzigingen van die uitvoeringsregelgeving. Deze regeling is nieuw ten opzichte van het huidige recht. Over het betrekken van de resultaten van deze internetconsultatie bij de onderbouwing van de regelgeving zijn in de Omgevingswet geen bepalingen opgenomen. Wel gelden de algemene beginselen van behoorlijk bestuur die deels zijn verwerkt in de Aanwijzingen voor de regelgeving. Op grond van die Aanwijzingen zal in de toelichting op de regelgeving aandacht moeten worden besteed aan de inbreng van externe partijen (incl. burgers). Er staat geen bestuursrechtelijke rechtsbescherming open tegen de uitvoeringsregelgeving op grond van de Omgevingswet, zodat ook hier geldt dat het niet of onvoldoende gelegenheid bieden tot participatie niet aan de bestuursrechter kan worden voorgelegd.

\section{- Decentrale algemene regels: omgevingsplan}

Het gemeentebestuur zal voor het grondgebied van de gemeente één omgevingsplan moeten vaststellen. In dit plan worden de gemeentelijke regels opgenomen die gaan over de fysieke leefomgeving en die bindend zijn voor burgers. Het gaat om regels over het gebruik van de grond en zich daarop bevindende bouwwerken die thans in het bestemmingsplan moeten worden opgenomen en de regels uit gemeentelijke verordeningen die betrekking hebben op de fysieke leefomgeving, zoals regels uit een kapverordening of een monumentenverordening. Evenals bij de omgevingsvisie en het omgevingsprogramma geldt een versterkte motiveringsplicht bij de vaststelling van het omgevingsplan. Aangegeven moet worden hoe de maatschappelijke participatie heeft plaatsgevonden en wat de resultaten daarvan zijn. ${ }^{25}$ Naar aanleiding van de behandeling in de Tweede Kamer is de regeling aangevuld met een kennisgevingsverplichting, waarbij is bepaald dat bij het voorne-

22 Art. 1.3.1 Besluit ruimtelijke ordening.

23 In sommige gevallen kan wel worden teruggevallen op de gemeentelijke inspraak- of participatieverordening. Hierin kunnen gemeenten regels opnemen over informele participatie of inspraak voor zover het gaat om de voorbereiding van gemeentelijk beleid (art. 150 Gemeentewet).

24 Art. 23.4 Omgevingswet. Van het ontwerp van een ministeriële regeling op grond van de Omgevingswet moet ook kennis worden gegeven in de Staatscourant (art. 10.0 Omgevingsbesluit).

25 Art. 10.2 lid 1 Omgevingsbesluit. 
men tot vaststellen van het omgevingsplan moet worden aangegeven hoe burgers, bedrijven en maatschappelijke organisaties worden betrokken bij de voorbereiding. ${ }^{26}$ Het omgevingsplan wordt net als de omgevingsvisie en het omgevingsprogramma voorbereid met de uitgebreide procedure van afd. 3.4 Awb. Dat betekent dat tegen het ontwerp-omgevingsplan door een ieder zienswijzen kunnen worden ingebracht. Tegen het omgevingsplan staat rechtsbescherming open.

Ten opzichte van het huidige recht brengt de Omgevingswet ten aanzien van participatie bij het omgevingsplan juridisch niet veel nieuws. Met uitzondering van een versterking van de verantwoordingsplicht, waarbij ook de resultaten van de participatie moeten worden aangegeven, kent het huidige Besluit ruimtelijke ordening een vergelijkbare regeling voor het bestemmingsplan. ${ }^{27}$ Ook de kennisgevingsverplichting over participatie is vergelijkbaar met het huidige artikel 1.3.1 Bro.

\subsection{Omgevingsvergunning}

De regeling inzake participatie bij de omgevingsvergunning is anders ten opzichte die in de huidige situatie. Onder de Omgevingswet krijgt de aanvrager van een omgevingsvergunning namelijk verplichtingen ten aanzien van vroegtijdige participatie. Bij de aanvraag moet worden aangegeven of burgers, bedrijven en/of maatschappelijke organisaties bij de voorbereiding van de aanvraag zijn betrokken. ${ }^{28}$ Indien er daadwerkelijk is geparticipeerd, moet de aanvrager bij de aanvraag gegevens verstrekken over hoe zij zijn betrokken en wat de resultaten daarvan zijn. ${ }^{29}$ Het is dus niet verplicht voor de aanvrager om gelegenheid te geven tot vroegtijdige participatie. De aanvrager kan volstaan met het aangeven dat er geen participatie heeft plaatsgevonden. Dit betekent ook dat het niet voorzien in participatie geen grond kan zijn voor het bevoegd gezag om de vergunningaanvraag buiten behandeling te laten. ${ }^{30}$ Een aantal Tweede Kamerleden vond deze regeling te vrijblijvend en bij amendement is later toegevoegd dat voor zover het de omgevingsvergunning voor een buitenplanse omgevingsplanactiviteit betreft, de gemeenteraad gevallen van activiteiten kan aanwijzen waarin participatie van en overleg met derden verplicht is, voordat een aanvraag kan worden ingediend. ${ }^{31}$ Met een omgevingsvergunning voor een buitenplanse omgevingsplanactiviteit wordt bedoeld een vergunning die ontwikkelingen mogelijk maakt die afwijken van de regels van het omgevingsplan. Indien niet aan deze participatieverplichting is voldaan, kan het bevoegd gezag de aanvraag in zo'n geval wel buiten p. 137-138.

27 Art. 3.1.6 lid 1 onder e Bro.

28 Art. 16.55 lid 6 Omgevingswet jo. art. 7.4 lid 1 Omgevingsregeling.

29 Art. 7.4 lid 2 Omgevingsregeling.

30 Art. 4:5 lid 1 Awb. Zie ook Lam \& Burgman-Linssen 2019.

31 Art. 16.55 lid 7 Omgevingswet. 
behandeling laten. Het bevoegd gezagis hiertoe echter niet verplicht. ${ }^{32}$ Deze nieuwe regeling biedt kortom een versterking van de participatiemogelijkheden van burgers, met daarbij wel de belangrijke kanttekening dat zowel de aanvrager als het bevoegd gezag veel beoordelingsruimte hebben bij de toepassing daarvan. Het niet bieden van de mogelijkheid tot vroegtijdige participatie hoeft daarom geen juridische belemmering te zijn voor vergunningverlening. De rechter zal vanwege die grote mate van beoordelingsruimte terughoudend toetsen aan deze participatieverplichting.

Het huidige recht kent geen regeling van vroegtijdige participatie bij de omgevingsvergunning, met uitzondering van de toepasselijkheid van de zienswijzenprocedure bij bepaalde omgevingsvergunningen. ${ }^{33}$ Zo kunnen bij de omgevingsvergunning voor (buitenplans) afwijken van het bestemmingsplan en bij de omgevingsvergunning milieu thans zienswijzen worden ingebracht tegen de ontwerpvergunning. Bij andere omgevingsvergunningen, zoals de omgevingsvergunning voor bouwen, is de zienswijzenprocedure niet van toepassing. In dit verband is het goed om op te merken dat onder de Omgevingswet op minder omgevingsvergunningen de zienswijzenprocedure van toepassing is. ${ }^{34} \mathrm{Zo}$ is voor de omgevingsvergunning voor een buitenplanse omgevingsplanactiviteit (in beginsel) niet langer deze procedure van toepassing. Dit betekent in vergelijking met het huidige recht een beperking van de participatiemogelijkheden. Een burger heeft immers geen mogelijkheid om zienswijzen tegen de ontwerp-omgevingsvergunning in te brengen. De regering wijst er in dit verband op dat het bevoegd gezag wel zienswijzen van derdebelanghebbenden kan vragen voorafgaand aan de vergunningverlening. ${ }^{35}$ Dat is echter niet verplicht.

Kortom, het bevoegd gezag heeft bij het bieden van participatiemogelijkheden voorafgaand aan de verlening van omgevingsvergunningen veel beleidsruimte. Participatie bij omgevingsvergunningen heeft daarmee een vrijblijvend karakter.

32 Art. 4:5 lid 1 Awb. Enigszins onduidelijk in dit verband is wel dat de participatieverplichting niet als indieningsvereiste in de Omgevingsregeling is opgenomen. Dit zal wel zo zijn bedoeld (Lam \& Burgman-Linssen 2019). Het verplicht melden van een milieubelastende activiteit op grond van het huidige Activiteitenbesluit milieubeheer is bijvoorbeeld ook een indieningsvereiste voor de aanvraag om een omgevingsvergunning, maar zonder die melding moet het bevoegd gezag de aanvraag buiten behandeling laten, nadat het de aanvrager in de gelegenheid heeft gesteld de aanvraag aan te vullen. Zie art. 8.41a Wet milieubeheer.

33 Op sommige omgevingsvergunningen is namelijk afd. 3.4 Awb van toepassing (zie art. 3.10 Wabo).

34 Afd. 3.4 Awb is alleen van toepassing in de gevallen genoemd in art. 10.24 Omgevingsbesluit, zoals voor bepaalde milieubelastende activiteiten. Wel kan de aanvrager van de omgevingsvergunning zelf verzoeken om of instemmen met toepassing van de zienswijzeprocedure (art. 16.65 lid 1 onder b Omgevingswet). Ook het bevoegd gezag kan in bepaalde omstandigheden deze procedure van toepassing verklaren indien het gaat om een omgevingsvergunning voor een buitenplanse omgevingsplanactiviteit (art. 16.65 lid 4 Omgevingswet).

35 Kamerstukken I 33962 E, antwoord vraag 65. Er wordt dan toepassing gegeven aan art. 4:8 Awb. 


\subsection{Projectbesluit}

\subsubsection{Inleiding}

Het projectbesluit vervangt verschillende projectbesluiten en -procedures waarmee op grond van het huidige recht projecten van publiek belang worden gerealiseerd en uitgevoerd. Deze projectprocedures zijn voornamelijk geïntroduceerd om de totstandkoming- besluitvormings- en rechtsbeschermingsprocedures voor de specifieke - voornamelijk infrastructurele - projecten van publiek belang te coördineren en te versnellen. Voor de realisering van deze vaak complexe projecten, zoals de aanleg en verbreding van belangrijke (snel-, spoor- en vaar)wegen, (buis)leiding- en kabeltracés, dijkversterkingen, ontpolderingen, etc., is namelijk niet alleen een projectbesluit van de initiatiefnemende bestuursorgaan nodig, maar zijn vaak ook besluiten van andere bestuursorganen nodig.

\subsubsection{De huidige projectbesluitregelingen}

In het huidige recht kennen zowel de Tracéwet (het projectbesluit), de Waterwet (het projectplan) als de Wet ruimtelijke ordening (facultatieve coördinatieregeling) regelingen voor projectbesluitvorming. Deze projectprocedures vertonen veel gelijkenis, maar wijken op bepaalde punten toch van elkaar af. Wat betreft participatie is de overeenkomst tussen deze projectprocedures dat op de voorbereiding van zowel het projectbesluit als de uitvoeringsbesluiten de zienswijzenprocedure van afdeling 3.4 Awb van toepassing is. Voor belanghebbenden die van de mogelijkheid tot inbreng van zienswijzen gebruik hebben gemaakt (of aan wie redelijkerwijs niet kan worden verweten dat zij dat niet hebben gedaan) staat in eerste en enige aanleg beroep tegen het besluit bij de Afdeling bestuursrechtspraak open. ${ }^{36}$

Tussen de projectprocedure van de Tracéwet en de andere projectprocedures bestaat vanuit participatieperspectief een belangrijk verschil. In de projectprocedure van de Tracéwet is namelijk als enige de zogenoemde 'sneller en beter'aanpak ${ }^{37}$ wettelijk geregeld. ${ }^{38}$ Op grond daarvan moet de minister alvorens een ontwerp-tracébesluit wordt vastgesteld een startbeslissing nemen, waarin wordt aangegeven dat er een verkenning wordt uitgevoerd naar bestaande of toekomstige problemen in het landelijke spoor-, water- of snelwegennet. ${ }^{39}$ Daarbij moet onder meer worden aangegeven op welke wijze burgers, maatschappelijk organisaties en betrokken bestuursorganen worden betrokken bij de verkenning. ${ }^{40} \mathrm{De}$ invulling van de participatieplicht is dan ook vormvrij. Om aan die plicht invulling te geven zijn wel buitenwettelijke codes en handreikingen opgesteld die het vorm-

37 De Sneller en Beter-aanpak is in de wet opgenomen naar aanleiding van het advies van de Commissie versnelling besluitvorming infrastructurele projecten (Commissie-Elverding) getiteld 'Sneller en beter', Stcrt. 2007, 216. Uitgebreider daarover Gierveld \& De Gier 2008.

38 De Sneller en Beter-aanpak is bij wet van 1 december 2011 in de Tracéwet opgenomen. Zie Stb. 2012, 595.

39 Art. 2 lid 1 Tracéwet.

40 Art. 2 lid 3 sub c Tracéwet. 
geven van het participatieproces kunnen ondersteunen, maar het gebruik daarvan is niet wettelijk verplicht. ${ }^{41}$

\subsubsection{Het projectbesluit onder de Omgevingswet}

Het projectbesluit in de Omgevingswet integreert en harmoniseert de verschillende projectprocedures die op grond van verschillende wetten voor de realisering van projecten van publiek belang gelden. Belangrijk verschil met de huidige projectbesluiten is dat op grond van de Omgevingswet het projectbesluit het omgevingsplan wijzigt met de regels die nodig zijn voor het uitvoeren en in werking hebben of in stand houden van het project. De gemeenteraad hoeft omgevingsplanregels dan ook niet te herzien om het project mogelijk te maken. Daarnaast kan het bevoegd gezag anders dan op grond van het huidige recht een integraal projectbesluit vaststellen (Groothuijse 2017; Besselink 2017). Dat wil zeggen dat het projectbesluit de benodigde uitvoeringsbesluiten vervangt, waarbij de beoordelingskaders voor die besluiten wel van toepassing blijven. Daardoor worden alle toestemmingen geïntegreerd in één besluit en is er één bevoegd gezag, één voorbereidingsprocedure, één besluitvormingsprocedure en één rechtsbeschermingsprocedure. In plaats van een integraal projectbesluit kan het bevoegd gezag er ook voor kiezen de uitvoeringsbesluiten overeenkomstig afdeling 3.5 Awb gecoördineerd voor te bereiden. ${ }^{42}$

\subsubsection{Projectbesluit en participatie}

Vanuit participatieperspectief is belangrijk dat de sneller en beter-aanpak uit de Tracéwet in grote lijnen op de vaststelling van het projectbesluit van toepassing is verklaard. Daarmee is de toepassing van deze aanpak verruimd tot alle projecten waarvoor een projectbesluit kan worden genomen. Ook zijn de participatieverplichtingen op bepaalde punten nader uitgewerkt. Belangrijke nuancering daarbij is dat het vaststellen van een projectbesluit - en daarmee ook de toepassing van de sneller en beter-aanpak - slechts voor een beperkt aantal projecten van publiek belang verplicht is gesteld. ${ }^{43}$ Voor andere projecten kan het bevoegd gezag een projectbesluit nemen, maar dat is niet verplicht. In dat geval zullen alle voor het project benodigde besluiten afzonderlijk moeten worden aangevraagd. ${ }^{44}$

De projectbesluitprocedure ziet er onder de Omgevingswet in grote lijnen als volgt uit. Het bevoegd gezag moet - vergelijkbaar met de procedure uit de Tracéwet - voor alle projecten waarvoor het een projectbesluit vaststelt, voorafgaand aan de terinzagelegging van het ontwerp-projectbesluit een verkenning uitvoeren

41 Zie bijvoorbeeld de Code Maatschappelijke Participatie, opgesteld door het ministerie van Infrastructuur en Waterstaat, te vinden op www.platformparticipatie.nl. Zie voor vele andere codes en handreikingen: https://aandeslagmetdeomgevingswet.nl/thema/inspiratiegids/praktische/ handreikingen-codes.

42 Art. 5.45 lid 1 jo. art. 16.7 Omgevingswet. De coördinatieregeling van afd. 3.5 Awb is van toepassing op projectbesluiten voor hoofdinfrastructuur en primaire waterkeringen (5.45 lid 2 jo. art. 16.7 Omgevingswet).

43 Het gaat om de aanleg en wijziging van de hoofdinfrastructuur en de primaire waterkeringen.

44 Wel kunnen deze met toepassing van de coördinatieregeling van afd. 3.5 Awb gecoördineerd worden voorbereid. 
naar mogelijke bestaande of toekomstige opgaven in de fysieke leefomgeving. Van het voornemen daartoe moet het bevoegd gezag openbaar kennisgeven. ${ }^{45}$ In die kennisgeving moet ook worden aangegeven of er voorafgaand aan het projectbesluit al dan niet een voorkeursbeslissing zal worden genomen.

In de voorkeursbeslissing spreekt het bestuur zijn voorkeur uit voor de wijze waarop het de opgave in de fysieke leefomgeving wil oplossen. ${ }^{46}$ Het betreft een politiek-bestuurlijke standpuntbepaling die niet juridisch bindend is en waartegen geen beroep bij de rechter openstaat. Wel kan een ieder zijn zienswijzen ten aanzien van een voorkeursbeslissing naar voren brengen. ${ }^{47}$ De voorkeursbeslissing moet uiteindelijk worden uitgewerkt in een of meer projectbesluiten, die juridisch bindend zijn en waartegen rechtsbescherming bij de bestuursrechter openstaat. Het nemen van een voorkeursbeslissing is een tussenstap in de trechtering van een abstracte opgave voor de fysieke leefomgeving naar een concreet projectbesluit. Die extra tussenstap is vooral van toegevoegde waarde bij complexe, controversiële en bestuurlijk gevoelige projecten, waarbij een brede verkenning en participatie wenselijk is. ${ }^{48}$ Het nemen van een voorkeursbeslissing is voor het bevoegd gezag daarom meestal niet verplicht. ${ }^{49}$

Uiterlijk bij aanvang van de verkenning moet het bevoegd gezag aangeven op welke wijze burgers, bedrijven en maatschappelijke organisaties bij de verkenning worden betrokken. Deze verplichting wordt in het Omgevingsbesluit ten opzichte van de Tracéwet op dit punt nader uitgewerkt. Het bevoegd gezag moet namelijk in ieder geval ingaan op:

- wie worden betrokken;

- waarover zij worden betrokken;

- wanneer zij worden betrokken;

- wat de rol van het bevoegd gezag is bij het betrekken van deze partijen; en

- waar aanvullende informatie beschikbaar is. ${ }^{50}$

Ook ten aanzien van de wijze waarop de kennisgeving van de participatiemogelijkheden plaatsvindt, worden in het Omgevingsbesluit nadere eisen gesteld. Deze kennisgeving moet op een zodanige wijze plaatsvinden dat het relevante publiek zo goed mogelijk wordt bereikt. ${ }^{51}$ Deze aanvullende eisen beogen het bevoegd gezag (of de initiatiefnemer) te stimuleren om tot een bewuste en afgewogen aanpak van de participatie te komen zonder deze aanpak wettelijk voor te schrijven. ${ }^{52}$ De eisen zijn echter weinig concreet, zodat het bevoegd gezag veel beoordelingsruimte heeft bij de invulling van deze verplichting en de rechterlijke toetsing aan

45 Op deze kennisgeving is art. 3:12 lid 1 en 2 Awb van toepassing.

46 Art. 5.49 Omgevingswet jo. art. 5.5 Omgevingsbesluit.

47 Art. 16.70 Omgevingswet jo. afdeling 3.4 Awb.

48 Kamerstukken II 2013/14, 33962, nr. 3, p. 184.

49 In bepaalde gevallen is een voorkeursbeslissing verplicht. Het gaat daarbij om de gevallen waar ook thans een voorkeursbeslissing verplicht is: aanleg en wijziging van rijkswegen, spoorwegen, vaarwegen (art. 5.47 lid 2 Omgevingswet jo. art. 5.4 Omgevingsbesluit, vgl. art. 2 lid 4 Tracéwet).

50 Art. 5.3 lid 1 Omgevingsbesluit.

51 Art. 5.3 lid 2 Omgevingsbesluit.

52 Art. 10 Wet openbaarheid van bestuur is van overeenkomstige toepassing, zodat informatie in de daar omschreven gevallen niet hoeft te worden verstrekt. 
deze eisen daarom terughoudend zal zijn. Om te waarborgen dat alle partijen op een gelijkwaardige wijze kunnen participeren voorziet artikel 5.3 lid 3 Omgevingsbesluit in de verplichting voor het bevoegd gezag om alle daarvoor benodigde informatie, zoals rapporten, tussentijdse resultaten van een verkenning, op een toegankelijke wijze beschikbaar te stellen. ${ }^{53}$

Belangrijke wijziging is dat een ieder met het oog op de verkenning uitdrukkelijk in de gelegenheid moet worden gesteld om binnen een bepaalde termijn mogelijke oplossingen voor de opgave in de fysieke leefomgeving aan te dragen. ${ }^{54}$ Het bevoegd gezag moet daarbij de uitgangspunten meegeven voor de redelijkerwijs in beschouwing te nemen oplossingen. ${ }^{55}$ Daarbij kan bijvoorbeeld worden gedacht aan de termijn of het budget waarbinnen het project moet worden uitgevoerd. ${ }^{56}$ Het bevoegd gezag moet vervolgens beslissen of een voorgedragen oplossing in beschouwing moet worden genomen. ${ }^{57}$

Een andere belangrijke wijziging is dat degenen die in de verkenningsfase daadwerkelijk een oplossing hebben voorgedragen, het bevoegd gezag kunnen verzoeken om daarover advies aan een onafhankelijk deskundige te vragen. ${ }^{58}$ Vanzelfsprekend kan het bevoegd gezag daartoe ook uit eigen beweging overgaan. De beslissing van het bevoegd gezag op een dergelijk verzoek is niet ingekaderd door de wet. De vraag is dan ook hoe een rechter een afwijzing van dat verzoek zal toetsen. Naar onze verwachting zal hij mede aan de hand van de algemene beginselen van behoorlijk bestuur beoordelen of het bevoegd gezag redelijkerwijs tot een afwijzing van dat verzoek kon overgaan. Mogelijk zal hij daarvoor aansluiten bij de jurisprudentie ten aanzien van de m.e.r.-regelgeving over de in het MER te beschrijven redelijke alternatieven, waarbij onder meer ook kosten en geschiktheid van het alternatief een rol mogen spelen. ${ }^{59}$

In de voorkeursbeslissing en het daaropvolgende projectbesluit ${ }^{60}$ moet het bevoegd gezag aangeven hoe burgers, bedrijven en maatschappelijk organisaties daarbij zijn betrokken en wat de uitgevoerde verkenning heeft opgeleverd. Daarbij moet het bevoegd gezag in ieder geval ook ingaan op de voorgedragen mogelijke oplossingen door derden en de daarover door deskundigen uitgebrachte adviezen. ${ }^{61}$

53 Stb. 2018, 290, p. 165.

54 Art. 5.47 lid 3, eerste zin Omgevingswet.

55 Art. 5.47 lid 3, tweede zin Omgevingswet.

56 Wij vragen ons af of die uitgangspunten ten tijde van kennisgeving van het voornemen dat er een verkenning wordt uitgevoerd altijd al heel concreet zijn te formuleren.

57 Art. 5.48 lid 3 Omgevingswet.

58 Art. 5.48 lid 2 Omgevingswet.

59 Zie art. 16.52 lid 2 sub b Omgevingswet jo. art. 11.16 lid 1 sub b Omgevingsbesluit. Volgens de regering hoeven in het kader van de MER niet alle denkbare alternatieven onderzocht te worden, kan het alternatievenonderzoek worden beperkt tot die alternatieven die het bestuursorgaan in staat stellen een goede afweging voor de besluitvorming te kunnen maken. Zie NvT consultatieversie Omgevingsbesluit, p. 180.

60 Zie art. 5.51 Omgevingswet. Als er een voorkeursbeslissing is genomen, kan in de motivering van het projectbesluit daarnaar worden verwezen.

61 Art. 5.5 Omgevingsbesluit. 


\subsection{Tussenconclusie}

Concluderend kan worden opgemerkt dat de participatieregeling in de Omgevingswet vooral bestaat uit motiverings- en verantwoordingsplichten, zonder dat de vormgeving van het participatieproces wettelijk wordt voorgeschreven. Ten opzichte van het huidige recht lijken de Omgevingswet en uitvoeringsregelgeving meer aandacht te hebben voor burgerparticipatie bij het inzetten van de juridische kerninstrumenten. Dat blijkt onder meer uit de verbreding van de sneller en beter-aanpak bij het projectbesluit, de verplichting voor de aanvrager van een omgevingsvergunning om aan te geven welke participatiemogelijkheden zijn geboden en wat de resultaten daarvan zijn en een nadere uitwerking van reeds bestaande motiverings- en verantwoordingsplichten. De juridische betekenis daarvan moet echter niet worden overschat. Het bevoegd gezag beslist namelijk in de meeste gevallen zelf of het een projectbesluit vaststelt voor de realisering van een project en daarmee dus ook of de sneller en beter-aanpak van toepassing is. De verantwoordingsplicht van de vergunningaanvrager verplicht bovendien niet tot participatie, waarbij het bevoegd gezag veel beleidsruimte heeft bij het verbinden van juridische consequenties bij de niet-naleving daarvan. Ondanks de toegenomen aandacht voor participatie, heeft de Omgevingswet echter ook belangrijke nadelige gevolgen voor de participatiemogelijkheden, aangezien de zienswijzenprocedure in veel gevallen wordt verruild voor de reguliere procedure, waarbij het bieden van een zienwijzemogelijkheid ten aanzien van de vergunningaanvraag niet verplicht is.

Al met al zijn wij dan ook van oordeel dat de Omgevingswet weinig juridische waarborgen biedt dat participatie bij omgevingsrechtelijke besluiten in de praktijk ook daadwerkelijk zal verbeteren ten opzichte van de huidige wet- en regelgeving. Of een verbetering zal optreden, is vooral afhankelijk van de mate waarin de bevoegde bestuursorganen participatie en het participatieproces daadwerkelijk serieus nemen.

In deze paragraaf hebben we gekeken naar de afzonderlijke juridische instrumenten. In de werkelijkheid grijpen deze instrumenten echter in elkaar. In de volgende paragrafen gaan wij in op het juiste moment van participatie binnen de besluitvormingsketen (paragraaf 4) en wat de rechter uiteindelijk kan doen als onvoldoende uitvoering wordt gegeven aan de participatieverplichtingen (paragraaf 5).

\section{Participatie op het juiste moment: stapeling en fragmentatie van participatie bij getrechterde besluitvorming}

Het omgevingsrecht kenmerkt zich in algemene zin door een getrechterde of gefaseerde besluitvorming. In omgevingsvisies en programma's worden strategische beleidskeuzes gemaakt, deze keuzes worden geconcretiseerd in omgevingsplannen en de uiteindelijke uitvoeringsaspecten worden neergelegd in omgevingsvergunningen. De trechtering heeft tot gevolg dat voor een specifiek project sprake is van opeenvolgende participatietrajecten, bij de verschillende instrumenten gelden immers eigen participatietrajecten. Dit kan onduidelijkheid voor de 
burger met zich meebrengen ten aanzien van de vraag welke aspecten wanneer naar voren kunnen of moeten worden gebracht. In de inleiding is reeds het voorbeeld gegeven van een windmolenpark, waarbij de locatiekeuze aan de orde is bij de omgevingsvisie. In de fase van vergunningverlening kunnen alleen nog uitvoeringsaspecten aan de orde komen, zoals de beperking van geluidhinder en slagschaduw. Indien een burger de locatiekeuze ter discussie wil stellen, zal dus op het juiste moment moeten worden geparticipeerd. Participatie in een vroegtijdig stadium is echter, zoals in paragraaf 2 is gebleken, weinig juridisch dwingend geregeld in de Omgevingswet. Het betreft een verantwoordingsplicht voor het bevoegd gezag, waarbij niet is bepaald op welke wijze de participatie moet worden vormgegeven.

Daarbij komt dat de meerwaarde van de verplichtingen ten aanzien van vroegtijdige informele participatie bij in het bijzonder de omgevingsvergunning kan worden betwijfeld. De aanvraag voor een omgevingsvergunning mag alleen worden getoetst aan de specifieke belangenkaders die daarvoor in de Omgevingswet en het Besluit kwaliteit leefomgeving zijn opgenomen (het zgn. specialiteitsbeginsel). Indien bijvoorbeeld in het informele participatietraject bij een omgevingsvergunning milieu bedenkingen enkel zijn geuit vanuit een planologisch perspectief, kan het bevoegd gezag deze niet meenemen bij de beoordeling van de vergunningaanvraag. Problematisch daarbij is ook dat er op verschillende momenten voor verschillende activiteiten waaruit een project bestaat omgevingsvergunningen kunnen worden aangevraagd - soms ook bij verschillende bevoegde bestuursorganen - waardoor de participatie bij die vergunningen dus ook wordt gefragmenteerd.

Voor zover omgevingsvergunningen strekken ter uitvoering van een project dat reeds zijn grondslag heeft in andere besluiten (bijvoorbeeld omgevingsplan) of beleidsdocumenten (bijvoorbeeld omgevingsvisies en programma's), valt er bij de omgevingsvergunningen vaak niet meer te participeren over nut en noodzaak van of alternatieven voor het project, maar slechts over de wijze waarop het project wordt uitgevoerd. Participatie over nut, noodzaak en alternatieven heeft dan al in een eerdere fase bij de vaststelling van de eerdere besluiten of beleidsdocumenten plaatsgevonden.

Het vaststellen van integrale projectbesluiten kan het probleem van fragmentatie of stapeling van participatiemomenten van uitvoeringsbesluiten enigszins tegengaan, waarbij van belang is dat onder de Omgevingswet het projectbesluit ook het omgevingsplan direct wijzigt. Door alle besluiten die nodig zijn voor de uitvoering van een project procedureel te integreren, ontstaat er namelijk één moment waarop burgers hun zienswijzen over een project naar voren kunnen brengen, zonder het verwijt te krijgen dat de zienswijze in een andere procedure naar voren moet of had moeten worden gebracht. De integratie van uitvoeringsbesluiten in het projectbesluit of het van toepassing verklaren van de coördinatieregeling van afdeling 3.5 Awb zijn beide echter facultatief. Gemeenten kunnen geen (integrale) projectbesluiten vaststellen. Wel kunnen zij bij de besluitvorming de Sneller en Beter-aanpak toepassen en de uitvoeringsbesluiten overeenkomstig de regeling 


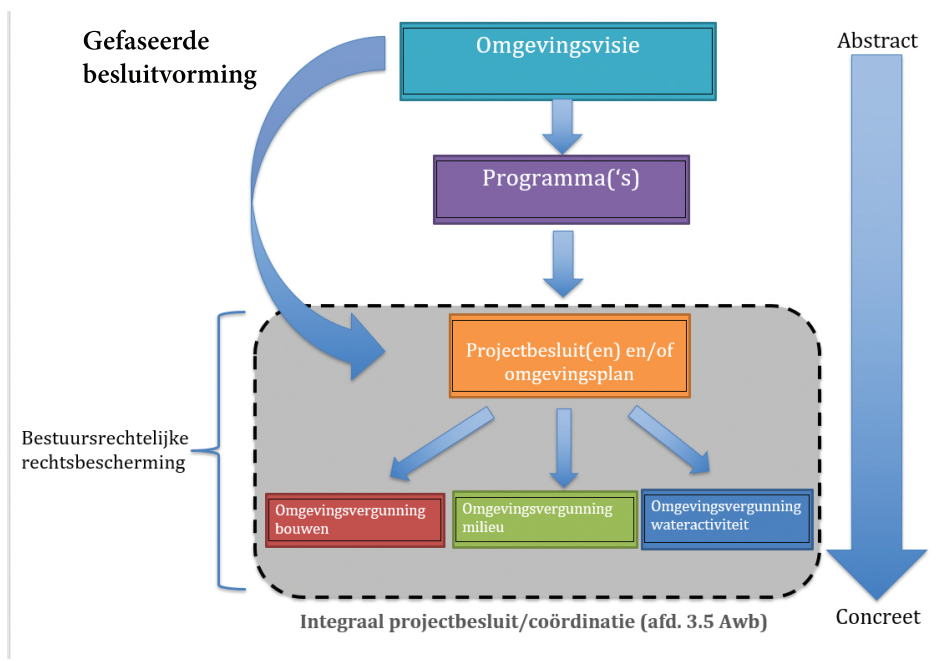

van afdeling 3.5 Awb gecoördineerd voorbereiden. ${ }^{62}$ De stapeling en fragmentatie worden door het vaststellen van integrale projectbesluiten niet geheel weggenomen, aangezien een projectbesluit ook zijn grondslag kan vinden in een beleidskeuze in een of meerdere omgevingsvisie(s) of programma('s), waarover ook zienswijzen naar voren konden worden gebracht. Het gaat daarbij veelal om abstracte globale beleidsuitspraken waarvan niet altijd duidelijk is wat dit voor de belangen van een bedrijf of burger betekent.

\section{Afdwingen van de naleving van wettelijke participatieverplichtingen}

In paragraaf 3 hebben wij de wettelijke verplichtingen ten aanzien van participatie bij de verschillende instrumenten van de Omgevingswet beschreven. De juridische waarde daarvan is afhankelijk van de mate waarin burgers de nakoming daarvan bij de rechter kunnen afdwingen. ${ }^{63}$ Interessante vraag is dan ook of, en zo ja, in hoeverre de nakoming van deze participatieverplichtingen door de burger in rechte kan worden afgedwongen. Om deze vraag te kunnen beantwoorden, moet worden vastgesteld wie die rechterlijke toetsing kunnen initiëren en op welke wijze de rechter aan deze participatieverplichtingen toetst.

\subsection{Rechtsbescherming bij de bestuursrechter}

Zoals in paragraaf 3 reeds is aangegeven, staat tegen de vaststelling en herziening van het omgevingsplan, de verlening (en weigering) van een omgevingsvergun-

63 Om te spreken met de Amerikaanse oud-president Abe Lincoln: 'Law without enforcement is just a good advice.' 
ning en de vaststelling van het projectbesluit rechtsbescherming bij de bestuursrechter open. ${ }^{64}$

Dit beroep op de bestuursrechter staat echter niet voor alle burgers open, maar slechts voor diegenenwier belangen rechtstreeks bij een besluit betrokken zijn. ${ }^{65}$ In het omgevingsrecht is daarvan - kort gezegd - sprake als iemand gevolgen van enige betekenis kan ondervinden van een omgevingsrechtelijk besluit vanwege bijvoorbeeld de afstand tot een toegestane activiteit, het zicht daarop of de milieugevolgen van de toegestane activiteit in de vorm van stank-, geluid,- of trillinghinder of toenemende luchtverontreiniging. Personen die geen belanghebbenden zijn bij een omgevingsrechtelijk besluit kunnen daartegen dus ook geen beroep instellen bij de bestuursrechter. Als jegens hen wettelijke participatieverplichtingen zijn geschonden, kunnen zij dit dan ook niet bij de bestuursrechter aan de orde stellen. Recent zijn overigens door de Rechtbank Limburg prejudiciële vragen gesteld aan het Hof van Justitie EU over de vraag of ook niet-belanghebbenden op grond van het Verdrag van Aarhus ${ }^{66}$ de schending van hun inspraakrechten bij de bestuursrechter zouden moeten kunnen aanvechten. ${ }^{67}$

Schending van de wettelijke participatieverplichtingen kan een belanghebbende alleen aan de bestuursrechter voorleggen als hij tijdig beroep instelt bij de bestuursrechter en daaraan voorafgaand tijdig bezwaar heeft gemaakt tegen het (primaire) besluit als de reguliere procedure van toepassing is, dan wel tijdig zienswijzen naar voren heeft gebracht tegen het ontwerpbesluit als de zienswijzenprocedure van afdeling 3.4 Awb van toepassing is (de zgn. besluitonderdelentrechter). ${ }^{68}$ In dat laatste geval is participatie van de belanghebbende door middel van het indienen van een zienswijze omtrent het ontwerpbesluit dus een noodzakelijke voorwaarde voor het instellen van beroep tegen het uiteindelijke besluit. Ook over de houdbaarheid van de besluitonderdelentrechter in het licht van het Verdrag van Aarhus heeft de Rechtbank Limburg prejudiciële vragen

64 Alleen tegen besluiten in de zin van art. 1:3 lid 1 Awb staat op grond van art. 8:1 Awb beroep bij de bestuursrechter open. Voor de inzet van de instrumenten van de Omgevingswet is daarbij het vereiste van publiekrechtelijk rechtsgevolg het belangrijkste criterium. Er is sprake van publiekrechtelijk rechtsgevolg als een bestuursorgaan op grond van de Omgevingswet of een daarop gebaseerde regeling een beslissing neemt die verandering brengt in de rechtspositie van de burger.

65 Art. 1:2 Awb.

66 Het Verdrag van Aarhus, waarbij zowel Nederland als de EU partij is, stelt bijzondere eisen aan de inspraak bij besluiten met aanzienlijke milieueffecten. Kortweg gaat het om de volgende eisen:

- $\quad$ adequate, tijdige en doeltreffende kennisgeving van een voorgenomen activiteit aan het betrokken publiek, waarbij het publiek tijdens de inspraakprocedure toegang heeft tot alle beschikbare informatie;

- $\quad$ redelijke termijnen voor inspraak op een moment dat alle opties open zijn;

- $\quad$ mogelijkheid tot mondelinge of schriftelijke reactie; en

- $\quad$ rekening houden met de resultaten van de inspraak.

67 Rb. Limburg ECLI:NL:RBLIM:2018:12159, AB 2019/177 m.nt. R.S. Wertheim en JM 2019/4 m.nt. E.J.H. Plambeck. Zie ook o.m. Verbeek 2019.

68 Art. 6:13 Awb. 
gesteld. ${ }^{69}$ De antwoorden van het Hof van Justitie EU op bovenstaande prejudiciele vragen zal moeten worden afgewacht. Deze kunnen van grote betekenis zijn voor de mogelijkheden voor inspraakgerechtigden om schendingen van participatieverplichtingen aan de bestuursrechter voor te leggen.

Als een belanghebbende tijdig bezwaar of zienswijzen heeft ingediend en vervolgens tijdig beroep heeft ingesteld bij de bestuursrechter, kan een succesvol beroep nog afstuiten op het relativiteitsvereiste. De bestuursrechter mag op grond van artikel 8:69a Awb een besluit namelijk niet vernietigen indien de rechtsregel waarmee een besluit in strijd is, kennelijk niet strekt ter bescherming van de belangen van de belanghebbenden die zich op die rechtsregel beroepen. De wettelijke participatieverplichtingen zijn in de wet opgenomen om de betrokkenheid van derden, waaronder ook belanghebbenden, bij de totstandkoming van het besluit te waarborgen, zodat een het beroep van een belanghebbende op schending van deze verplichtingen niet snel zal afstuiten op het relativiteitsvereiste.

Kortom, alleen belanghebbenden bij een besluit die tijdig zienswijzen hebben ingebracht, kunnen de schending van de wettelijke participatieverplichtingen bij de bestuursrechter voorleggen.

\subsection{Rechtsbescherming bij de burgerlijke rechter als restrechter}

Voor zover schendingen van de wettelijke participatieverplichtingen niet kunnen worden voorgelegd aan de bestuursrechter (zie par. 5.1), kunnen deze worden voorgelegd aan de burgerlijke rechter. ${ }^{70}$ Voor zover de overheid met de inzet van deze juridische instrumenten een onrechtmatige daad pleegt jegens één of meer burgers, kunnen deze burgers een onrechtmatigedaadsactie starten bij de burgerlijke rechter. In theorie kunnen zij door middel van een gebodsactie bij de burgerlijke rechter vorderen dat de participatieverplichtingen alsnog worden nagekomen. Daarvoor is wel vereist dat zij voldoende procesbelang hebben. ${ }^{71}$ De privaatrechtelijke handhaving van participatieverplichtingen bij de totstandkoming van niet bij de bestuursrechter appellabele besluiten door middel van een gebodsactie is nog onontgonnen terrein. ${ }^{72}$ Bovendien is de procedure bij de burgerlijke rechter minder aantrekkelijk voor de burger dan de bestuursrechtelijke procedure, omdat de griffiegelden hoger zijn, de proceskosten van de gedaagde partij moeten worden vergoed als de vordering geheel of gedeeltelijk wordt afgewezen en de procedure over het algemeen langer duurt.

Zie o.m. HvJ EU 15 oktober 2015, zaak C-137/14, ECLI:EU:C:2015:683 (Commissie tegen Duitsland), $A B$ 2015, 447 m.nt. Ch.W. Backes; ABRvS 2 december 2015, ECLI:NL:RVS:2015:3703, JM 2016, 10 m.nt. G.A.J.M. Hoevenaars. Backes en Hoevenaars plaatsen in hun annotaties vraagtekens bij de houdbaarheid van de onderdelentrechter.

70 De burgerlijke rechter fungeert in dat geval als restrechter.

71 Daarnaast moet sprake zijn van toerekenbaar onrechtmatig overheidshandelen en moet de geschonden rechtsregel strekken ter bescherming van de belangen van de burger die zich daarop beroept. Aangezien het bestuursorgaan een wettelijke participatieverplichting heeft geschonden die juist strekt tot de bescherming van de belangen van de betrokken burger, is daarvan al snel sprake.

72 Dat geldt ook voor de gebodsactie in algemene zin. Zie daarover o.m. Bleeker 2017. 


\subsection{Rechterlijke toetsing participatieverplichtingen}

Op welke wijze toetst de rechter de (niet-)nakoming van de participatieverplichtingen? Ten eerste is van belang dat een belanghebbende zelf in het kader van een beroep tegen een appellabel besluit moet aanvoeren dat het bevoegd gezag de wettelijke participatieverplichtingen heeft geschonden. De rechter zal daar niet ambtshalve toe overgaan.

Op grond van het huidige recht toetst de rechter tamelijk formalistisch of aan de wettelijke participatieverplichtingen wordt voldaan. Formeel vangt de wettelijke procedure aan met een aanvraag om een besluit te nemen of met de terinzagelegging van een ontwerpbesluit als het een besluit betreft dat wordt voorbereid met afdeling 3.4 Awb. Het niet bieden van inspraak ${ }^{73}$ of het niet nakomen van inspraakverplichtingen die op grond van inspraakverordening gelden ${ }^{74}$ voorafgaand aan formele aanvang van de procedure kan volgens vaste rechtspraak de rechtmatigheid van het besluit niet aantasten.

Als de openbare uniforme voorbereidingsprocedure van afdeling 3.4 Awb van toepassing is, toetst de bestuursrechter of het ontwerpbesluit conform de regels van Awb ter inzage is gelegd en van die terinzagelegging openbaar kennis is gegeven, of een ieder daarover zienswijzen kon indienen en of het bevoegd gezag gemotiveerd heeft aangegeven hoe het is omgegaan met de naar voren gebrachte zienswijzen.

Indien het Verdrag van Aarhus op de besluitvorming van toepassing is, zal de inspraak moeten voldoen aan de eisen die artikel 6 daaraan stelt. ${ }^{75}$ Een belangrijke eis die aan inspraak wordt gesteld is dat deze vroegtijdig plaatsvindt, als alle opties nog open zijn. ${ }^{76}$ Dat wil zeggen dat burgers nog daadwerkelijk in staat moeten zijn om invloed uit te oefenen op het besluitvormingsproces. ${ }^{77}$ Naar het oordeel van de Afdeling wordt met toepassing van de zienswijzenprocedure van afdeling 3.4 Awb aan die eis voldaan, aangezien op het moment dat zienswijzen tegen het ontwerpbesluit naar voren kunnen worden gebracht nog geen beslissing over het ontwerpbesluit is genomen. ${ }^{78}$ De Afdeling toetst in veel gevallen niet of in het concrete geval op dat moment de opties ook daadwerkelijk nog open waren. In de literatuur is kritiek geuit op deze formele benadering van de Afdeling en wordt betwijfeld of deze wel in overeenstemming is met artikel 6 lid 4 Verdrag van Aarhus op grond waarvan inspraak moet plaatsvinden op een moment waarop alle opties nog open zijn. ${ }^{79}$ Ook de civiele voorzieningenrechter heeft

73 Zie bijvoorbeeld ABRvS 21 oktober 2015, ECLI:NL:RVS:2015:3248.

74 Zie o.m. ABRvS 23 december 2015, ECLI:NL:RVS:2015:3919; ABRvS 1 juli 2015, ECLI:NL:RVS: 2015:2068; ABRvS 24 maart 2010, ECLI:NL:RVS:2010:BL8680; ABRvS 5 maart 2008, ECLI:NL:RVS:2008:BC5753, Gst. 2008, 49 m.nt. Teunissen.

75 De EU heeft de inspraakverplichtingen uit het Verdrag van Aarhus geïmplementeerd in de Inspraakrichtlijn, de MER-richtlijn en de Richtlijn Industriële emissies (RIE). Zie par. 2.1.

76 Art. 6 lid 4 Verdrag van Aarhus.

77 HvJ EU 15 januari 2013, C-416/10, ECLI:EU:C:2013:8, MenR 2013/107 m.nt. J.H. Jans.

78 Zie o.m. ABRvS 21 februari 2018, ECLI:NL:RVS:2018:616, MenR 2018/84, m.nt. J. Gundelach \& J. Kevelam en ABRvS 16 september 2015, ECLI:NL:RVS:2015:2839.

79 Zie bijvoorbeeld Koers \& Bröring 2017, p. 161-166 en Schueler 2014. Volgens Schueler is het op zijn minst twijfelachtig of de uitgebreide voorbereidingsprocedure van afdeling 3.4 Awb aan deze eis voldoet. 
daarbij zijn twijfels. ${ }^{80}$ Naar zijn oordeel valt moeilijk vol te houden dat in alle gevallen de participatierechten van burgers voldoende zijn gewaarborgd door de mogelijkheden die de zienswijzenprocedure biedt. ${ }^{81}$ Indien mag worden verwacht dat in de zienswijzenprocedure niet alle opties meer open zijn en er in zoverre geen doeltreffende inspraak zal plaatsvinden, verlangt artikel 6 lid 4 Verdrag van Aarhus (en de MER-richtlijn) volgens de voorzieningenrechter dat in dergelijke gevallen de burgerparticipatie (ook) vóór de zienswijzenprocedure gestalte moet krijgen. Aangezien de bestuursrechter het bieden van inspraak voorafgaand aan de zienswijzenprocedure van een besluit niet toetst, ligt er volgens de voorzieningenrechter een taak voor de burgerlijke rechter om te toetsen of de in die fase geboden inspraak voldoet aan de eisen van artikel 6 lid 4 Verdrag van Aarhus.

Van belang is dat in de totale keten van de besluitvorming steeds op de juiste momenten voldoende inspraak is geboden. In onze ogen zal ook de bestuursrechter bij de toetsing van het besluit moeten bezien of dat het geval is geweest. Dat heeft als bijkomend voordeel dat de civiele rechter die toets niet meer hoeft te verrichten. Bovendien kunnen schendingen van inspraakverplichtingen in de voorfase van deze niet bindende beleidsdocumenten mogelijk worden hersteld in de zienswijzenfase van het appellabele besluit, mits in die fase alle opties dan nog open zijn. ${ }^{82}$ Dat betekent dat het bevoegd gezag alsnog inhoudelijk zal moeten ingaan op de zienswijzen die zien op de eerder gemaakte keuzes in beleidsdocumenten die aan het appellabele besluit ten grondslag liggen. Het schenden van participatieverplichtingen in de voorfase kan op die manier als een boemerang terugkomen in de latere fase van de besluitvorming over een project. Dat kan een stimulans vormen voor het bestuur om de participatieverplichtingen vanaf het begin van besluitvormingsketen serieus te nemen.

In de jurisprudentie van de Afdeling zijn wel voorbeelden te vinden van een meer materiële toetsing van de inspraakverplichtingen in de gehele besluitvormingsketen. ${ }^{83}$

In haar uitspraak van 24 maart 2010 bijvoorbeeld oordeelt de Afdeling dat hoewel schending van de inspraakverplichting voorafgaand aan de bestemmingsplanprocedure over de locatie van een OV-knooppunt geen gevolgen kan hebben voor de rechtmatigheid van het bestemmingsplan, de raad er niet van mag uitgaan dat die locatiekeuze bij de start van de bestemmingsplanprocedure niet meer ter discussie staat. De raad moest dan ook een in de zienswijze over het ontwerp-bestemmingsplan voorgestelde alternatieve locatie bij de vaststelling van het bestemmingsplan betrekken. ${ }^{84}$

80 Vz. Rb. Noord-Nederland 9 november 2017, ECLI:NL:RBNNE:2017:4278.

81 In de totstandkoming van de Omgevingswet en de daarop gebaseerde besluiten zijn volgens de voorzieningenrechter aanwijzingen te vinden dat ook de wetgever dit onderkent.

82 Ook Verbeek acht het niet uitgesloten dat herstel mogelijk is, mits alle opties dan nog open zijn. Zie J. Verbeek, Inspraak volgens het Verdrag van Aarhus, SEW 2019/5, p. 211.

83 Zie bijvoorbeeld ook: ABRvS 18 juli 2018, ECLI:NL:RVS:2018:2454; ABRvS 4 mei 2016, ECLI:NL:RVS:2016:1228; ABRvS 17 januari 2018, ECLI:NL:RVS:2018:141. 
Een ander voorbeeld betreft de uitspraak van de Afdeling over de aanleg van een nieuwe wegverbinding tussen de A13 en de A16. ${ }^{85}$ Nadat de Afdeling heeft vastgesteld dat aan de participatieverplichtingen ten aanzien van het tracébesluit is voldaan, oordeelt zij dat andere mogelijkheden tot participatie en overleg zijn geboden, waaronder gebiedstafels. De Afdeling heeft dan ook niet de overtuiging gekregen dat niet voldoende reële mogelijkheden zijn geboden om ideeën over de inpassing van de nieuwe snelweg naar voren te brengen. Ook gaat de Afdeling in op de fase voorafgaand aan de zienswijzenprocedure ten aanzien van het tracébesluit. Appellanten hebben hun reactie kunnen geven op de startnotitie waarin de in het tracébesluit gekozen oplossing als oplossingsrichting wordt vermeld. Op die reactie heeft de minister inhoudelijk gereageerd, waarbij hij is ingegaan op de aangedragen alternatieven en onderzoek heeft laten doen naar het probleemoplossend vermogen daarvan. De Afdeling concludeert dan ook dat op verschillende momenten in het besluitvormingsproces zienswijzen naar voren konden worden gebracht over alternatieven van de nieuwe A16 en dat de naar voren gebrachte zienswijzen ook zijn meegewogen.

Uit de jurisprudentie van de Afdeling bestuursrechtspraak wordt niet helemaal duidelijk of de formele of materiële benadering wordt gevolgd (Verbeek 2019). Een materiële benadering zal naar ons oordeel de nakoming van de wettelijke participatieverplichtingen in de gehele besluitvormingsketen kunnen bevorderen. In het kader van de rechterlijke toetsing aan de algemene beginselen van behoorlijk bestuur kan participatie ook een belangrijke rol spelen. Op grond van onder meer het zorgvuldigheidsbeginsel (art. 3:2 Awb), evenredigheidsbeginsel (art. 3:4 Awb) en motiveringsbeginsel (art. 3:46 Awb) zal het bevoegd gezag namelijk nog los van enige wettelijke participatieverplichting de bij het besluit betrokken belangen (en feiten) moeten inventariseren, deze belangen moeten afwegen en die afweging moeten motiveren. Voor een goede weging van die belangen zullen degenen wier belangen zijn betrokken in staat moeten worden gesteld om die belangen voor het voetlicht te brengen en nader toe te lichten. Het serieus nemen van participatie(verplichtingen) is in dat kader dus ook van belang.

Dat is des temeer het geval omdat er een beweging is waar te nemen naar een indringendere toetsing aan het evenredigheidsbeginsel door de bestuursrechter. AG Widdershoven bepleitte in 2017, in navolging van andere auteurs, al dat in bepaalde gevallen een stringentere, aan het EU recht ontleende evenredigheidstoets zou moeten worden toegepast. ${ }^{86}$ De bestuursrechter zou zich, aldus de AG, bij de doel-middeltoets van een overheidsproject kunnen oriënteren op de door het Hof van Justitie toegepaste drietrapstoets aan geschiktheid, noodzakelijkheid en evenwichtigheid. In het bijzonder gaat het daarbij ook om de verplichting van het bevoegd gezag om ook minder belastende alternatieven van het project te onderzoeken. Een indringender toets dwingt bevoegde bestuursorganen om expliciet andere betrokken belangen te identificeren en de weging daarvan ten 
opzichte van het project te expliciteren. Ook deze ontwikkeling zal het bevoegd gezag mogelijk kunnen aanzetten tot actiever betrekken van het publiek bij de plan- en besluitvorming.

\section{Conclusie en oplossingsrichtingen}

De hoofdvraag van deze bijdrage was op welke wijze burgerparticipatie in de Omgevingswet juridisch is vormgegeven en of de betrokkenheid van burgers daadwerkelijk juridisch beter is geborgd.

Belangrijkste conclusies zijn de volgende. De wettelijke participatieverplichtingen zijn onder de Omgevingswet (te) vrijblijvend vormgegeven. Aan het niet nakomen van de verplichtingen zijn weinig tot geen juridische consequenties verbonden en ze zijn door de burger ook lastig afdwingbaar bij de rechter. Er is bovendien weinig aandacht voor rol van participatie in de verhouding tussen de verschillende juridische instrumenten, waardoor het voor een burger onnavolgbare consequenties kan hebben indien op een 'verkeerd' moment (bij een verkeerd besluit) wordt geparticipeerd.

Om tegemoet te komen aan deze tekortkomingen zou naar onze mening de wetgever op verschillende punten de wetgeving kunnen aanscherpen door de participatieverplichtingen een minder vrijblijvende uitwerking te geven. Zo zou bij de participatieregeling voor de omgevingsvergunning kunnen worden bepaald dat indien de aanvrager de betrokkenheid van burgers niet of onvoldoende verantwoordt, de vergunning buiten behandeling moet blijven. Ook zou het projectbesluit voor meer typen (complexe) projecten wettelijk kunnen worden voorgeschreven, zodat de sneller en beter-aanpak vaker verplicht is. ${ }^{87}$ Dat zou ook de gefragmenteerde participatiemogelijkheden bij de verschillende besluiten die nodig zijn voor de uitvoering van een project bundelen. Daardoor kan de participatie worden gedefragmenteerd en voor de burger worden vereenvoudigd.

Om geen valse verwachtingen bij de burger te wekken, zal bij alle participatiemogelijkheden die de burger (moeten) worden geboden, moeten worden aangegeven binnen welke juridische, beleidsmatige en financiële randvoorwaarden participatie mogelijk is. Met andere woorden: waarover participatie wel, maar ook waarover participatie in het desbetreffende geval niet (meer) kan gaan. Daarbij is van belang dat de participatie onder de Omgevingswet, zeker bij grote complexe projecten, gefaseerd (of getrechterd) plaatsvindt, waarbij het onderwerp van de participatie steeds concreter, uitvoeringsgerichter en daarmee ook steeds beperkter wordt.

De bestuursrechter zou een belangrijke rol kunnen spelen bij het stimuleren van het bestuur om participatie in alle fasen van de besluitvorming serieus te nemen, door bij de toetsing van besluiten rekening te houden met de gelaagdheid van de besluitvorming. 
Dit alles neemt niet weg dat het creëren van draagvlak nooit doorslaggevend kan zijn in de besluitvorming, dit zou immers op gespannen voet staan met de democratische legitimatie van besluitvorming.

\section{Referenties}

Akerboom, S., Between Public Participation and Energy Transition: The Case of Wind Farms (diss. UvA), Amsterdam 2018.

Besselink, H.J.M., 'Integratie als keuze: het projectbesluit voor waterschappen in de nieuwe Omgevingswet', Tijdschrift voor Omgevingsrecht 2017-4, p. 191-195.

Bleeker, T.R., 'De knellende criteria van het rechterlijk bevel en verbod', in: Vijftig Weeffouten in het BW (p. 185-196), Nijmegen: Ars Aequi Libri 2017.

Bröring, H.E. \& K.J. de Graaf (red.), Bestuursrecht, Den Haag: Boom juridisch 2016.

De Haas, D.C.E. \& A.I. Tsheichvili, 'Grootschalige windparken: inspraak op een vroeg genoeg moment?', MenR 2018/109.

Gierveld, H.A.J. \& A.A.J. de Gier, 'Anders dus sneller?', Tijdschrift voor Omgevingsrecht 2008-3, p. 85-89.

Groothuijse, F.A.G., 'Inhoud en reikwijdte van het projectbesluit voor 'natte' waterstaatswerken', Tijdschrift voor Omgevingsrecht 2017-4, p. 184-190.

Lam, T.E.P.A. \& C.M.A.P. Burgman-Linssen, 'Invoeringswet Omgevingswet aangenomen door de Tweede Kamer', TBR 2019-48.

Uylenburg, R., 'Draagvlak, veranderingen en energietransitie', MenR 2019-63.

Verbeek, J., 'Inspraak volgens het Verdrag van Aarhus', SEW 2019-5, p. 205-213. 